ORIGINAL ARTICLE

\title{
Hospitalisations among seafarers on merchant ships
}

\author{
H L Hansen, F Tüchsen, H Hannerz
}

Occup Environ Med 2005;62:145-150. doi: 10.1136/oem.2004.014779

See end of article for authors' affiliations ......................

Correspondence to: Dr H L Hansen, Vedelsgade 17A, DK7100 Vejle, Denmark; hlhansen@dadlnet.dk

Accepted 30 October 2004

\begin{abstract}
Aims: To study morbidity among active seafarers in the merchant navy in order to clarify possible work related morbidity and the morbidity related to work and lifestyle where possible preventive measures may be initiated.

Methods: From a register in the Danish Maritime Authority a cohort of Danish merchant seafarers who had been actively employed at sea in 1995 was identified. For each seafarer, information on all employment periods at sea, charge aboard, and ship was available. The cohort was linked with the National In-patient Register in Denmark. Standardised hospitalisation ratios (SHRs) were calculated for all major diagnostic groups using all gainfully employed as reference.

Results: Seafarers were shown to be inhomogeneous, with significant differences in SHRs for the same disease groups between different groups of seafarers depending on charge and ship type. SHRs for lifestyle related diseases were high, although rates for acute conditions, such as acute myocardial infarction, were low, probably due to referral bias, as acute conditions are likely to cause hospitalisation abroad, and thus are not included in the study. SHRs for injury and poisoning were high, especially for ratings and officers aboard small ships.

Conclusion: Despite pre-employment selection, a large proportion of the seafarers constitute a group of workers with evidence of poor health probably caused by lifestyle. The subgroups with high risk of hospitalisation due to lifestyle related diseases also had an increased risk of hospitalisation due to injury and poisoning.
\end{abstract}

$M$ erchant seafaring is an occupation which differs from other occupations in many aspects. Seafarers live in their workplace for extended periods of time; they often work long hours, and usually around the clock shifts. The movement of the ship causes musculoskeletal strain, and noise and vibration are permanently present. ${ }^{1}$ Occupational accidents are, especially on smaller vessels, frequent and often serious. ${ }^{2}$ In the engine rooms of ships there are exposures to different type of hydrocarbons, ${ }^{3}$ and on ships carrying oil products and chemicals, exposure to carcinogenic substances may take place. ${ }^{4}$ Smoking is frequent in most maritime environments, and obesity has become frequent as the manual workload has been reduced and food become more abundant. ${ }^{5}$ Many seafarers are, as a part of the job, international travellers, and are known to have a risk of hepatitis A and B, HIV infection, and tuberculosis. ${ }^{6}$

Seafarers from Denmark are known to have a risk of early death due to lifestyle related diseases, suicide, and accidents, not only aboard but also ashore. ${ }^{7}$ Seafarers from Scandinavia have a high risk of lifestyle related cancers, ${ }^{8}$ but little is known about the occurrence of non-fatal diseases and accidents outside the workplace.

The purpose of this study was to investigate the morbidity among active seafarers in the merchant navy using hospitalisation data as a measure for morbidity. The aim was to clarify possible work related morbidity, and the morbidity related to work and lifestyle where possible preventive measures may be initiated.

\section{METHODS}

The seafarers

This study is a historical cohort study. The cohort of seafarers was established on data from a register at the Danish Maritime Authority in which all seafarers aboard Danish registered merchant vessels are recorded each time they are signed on and off. ${ }^{2}$ The information recorded is based on copies of employment contracts. The follow up in this study includes a group of seafarers with active employment aboard a Danish merchant ship in 1995. A total of 8605 men signed on in 1995 and 7401 were employed for more than three months. A group of 926 females with three months or more of active service were analysed as well. A three month limit was chosen as three months of active service at sea corresponds to six months of work and thus the most important employment in the calendar year in question. This was done to make the group comparable with the reference groups.

The individual seafarers were classified into different occupational groups and ship types depending on their charge on their first employment in 1995. Only seafarers with official residence in Denmark at the end of 1995 were included. By using the register in the Danish Maritime Authority, it was possible to get detailed information on position aboard and on the type of ship at which the individual had been employed.

\section{The reference groups}

The results were compared with the results for all men and women, respectively, recorded in the Employment Classification Module (ECM). The study only includes individuals aged 20-59 at the start of follow up on 1 January 1996. The results were also compared with a group of fishermen. This group was identified directly in the ECM where they make up a well defined group of workers. The follow up period for the fishermen was 1995-99. In short, all adults in Denmark are classified annually according to occupation in the ECM. The ECM contains information concerning economic activity, employment status, occupation, and industry as described in detail elsewhere. ${ }^{9}$ Each individual is classified according to his or her most important occupation each year.

\section{Follow up and analysis}

The follow up for each individual member of the cohort and each diagnosis started on 1 January 1996, and continued for five years or hospitalisation for the specific diagnosis, 


\section{Main messages}

- Hospitalisation ratios for both male and female seafarers are above the ratios for the general workforce for several diagnostic groups, including diseases related to lifestyle and accidents.

- Seafarers are an inhomogeneous group where hospitalisation ratios depend on charge and type of ship they are employed in.

- Subgroups of seafarers with a high risk of hospitalisation due to accidents and other external causes also have an excess risk of hospitalisation due to lifestyle related diseases.

- The hospitalisation ratios for diseases of the locomotor system are, in contrast to what is seen among fishermen, close to normal.

- Female seafarers approach the health profile of male seafarers.

emigration, or death, whichever came first. As only one hospitalisation for a specific diagnosis is counted, the results may be interpreted as the incidence of the diagnosis in question. Standardised hospitalisation ratios (SHRs) were calculated by dividing the observed number by the expected number of hospitalisations in the whole population of seafarers or fishermen or subgroups of seafarers and multiplying it by 100. The expected number was based on age specific incidence rates for all gainfully employed men in Denmark, and 95\% confidence intervals were calculated.

In addition to the above analysis, a Poisson regression was performed for each of the studied diagnoses. In this step, only the male subjects were included, and we did not exclude those employed for less than three months in 1995. The model contained the following variables: ship type (three

\section{Policy implications}

- The maritime industry should be a target for preventive measures focusing on lifestyle related diseases and factors causing accidents.

- Health promoting initiatives targeting seafarers should take into account the inhomogeneous composition of the workforce employed aboard merchant ships.

- Female seafarers seem to be an especially vulnerable group in need of special attention.

categories), charge (two categories), whether the first ship employment in 1995 concerned domestic or international trade (two categories), and whether or not the person had been employed on a ship for more than three months in 1995 (two categories). We only regarded main effects and we used the "genmod" procedure in SAS (see SAS/STAT Software: Syntax, version 6, first edition) to perform the analyses. The age adjusted expected number of cases was used as an offset.

\section{The Central Population Register and the National In-patient Register}

From the Central Population Register, information on death and emigration was obtained. The National In-patient Register combines information from all county registers in Denmark. It contains data on all hospitalisations in public and private hospitals in Denmark. When a patient is discharged, a primary diagnosis for the hospital admission is given and coded according to the International Classification of Diseases (ICD) code. Since 1994, all diagnoses have been coded according to ICD-10. The primary diagnosis is used in this study. The diagnoses have been divided into the main groups used in the ICD-10

Table 1 Standardised hospitalisation ratios (SHRs) for selected diagnoses among male seafarers with at least three months employment in 1995 and men who had fishing as their most important employment in 1994

\begin{tabular}{|c|c|c|c|c|c|c|}
\hline \multirow[b]{2}{*}{ Diagnosis text and ICD-10 code } & \multicolumn{3}{|l|}{ Seafarers } & \multicolumn{3}{|l|}{ Fishermen } \\
\hline & $\begin{array}{l}\text { Observed } \\
\text { number }\end{array}$ & SHR & $95 \% \mathrm{Cl}$ & $\begin{array}{l}\text { Observed } \\
\text { number }\end{array}$ & SHR & $95 \% \mathrm{Cl}$ \\
\hline Infectious and parasitic diseases (A00-B99) & 59 & 94 & 71 to 121 & 98 & 80 & 65 to 97 \\
\hline Neoplasms (COO-C97) & 162 & 133 & 114 to 155 & 166 & 125 & 107 to 146 \\
\hline Endocrine and nutritional diseases (EO0-E99) & 83 & 278 & 199 to 387 & 48 & 88 & 65 to 116 \\
\hline Diseases of the circulatory system (100-199) & 303 & 108 & 96 to 121 & 353 & 118 & 106 to 131 \\
\hline Ischaemic heart disease (120-125) & 86 & 88 & 70 to 108 & 116 & 108 & 90 to 130 \\
\hline Myocardial infarction (I21) & 28 & 66 & 44 to 95 & 49 & 99 & 73 to 130 \\
\hline Varicose veins of lower extremities (183) & 22 & 108 & 67 to 163 & 38 & 175 & 124 to 240 \\
\hline Diseases of the respiratory system (J00-J99) & 154 & 115 & 98 to 134 & 153 & 114 & 97 to 133 \\
\hline Diseases of the digestive system (KOO-K93) & 331 & 112 & 101 to 125 & 403 & 129 & 117 to 142 \\
\hline Gastric or duodenal ulcer (K25-K27) & 17 & 94 & 54 to 150 & 37 & 159 & 112 to 219 \\
\hline Gastritis and duodenitis (K29) & 23 & 166 & 105 to 249 & 41 & 248 & 178 to 337 \\
\hline Inguinal hernia (K40) & 84 & 128 & 102 to 158 & 73 & 97 & 76 to 122 \\
\hline $\begin{array}{l}\text { Diseases of the musculoskeletal system and connective tissue } \\
\text { (M00-M99) }\end{array}$ & 206 & 90 & 79 to 104 & 342 & 144 & 129 to 160 \\
\hline Arthrosis of the hip (M16) & 9 & 70 & 32 to 133 & 11 & 81 & 41 to 146 \\
\hline Arthrosis of the knee (M17) & 16 & 117 & 67 to 191 & 25 & 159 & 103 to 234 \\
\hline Cervical disc disorders (M50) & 12 & 217 & 112 to 379 & 11 & 159 & 79 to 285 \\
\hline Lumbar disc disorders (M51) & 34 & 81 & 56 to 113 & 82 & 174 & 138 to 215 \\
\hline Diseases of the genitourinary system (N00-N99) & 108 & 98 & 81 to 119 & 114 & 97 & 80 to 116 \\
\hline Injury and poisoning (S00-T99) & 467 & 115 & 105 to 126 & 651 & 171 & 159 to 185 \\
\hline $\begin{array}{l}\text { Fractures (S02, S12, S22, S32, S42, S52, S62, S72, S82, S92, } \\
\text { T02, T08, T10, T12) }\end{array}$ & 168 & 132 & 114 to 154 & 227 & 182 & 159 to 207 \\
\hline $\begin{array}{l}\text { Internal injuries (S15-16, S25-27, S35-37, S45-46, S55-56, } \\
\text { S65-66, S75-76, S85-86, S95-96) }\end{array}$ & 34 & 76 & 52 to 106 & 52 & 121 & 90 to 158 \\
\hline Dislocation, sprain, and strain of joints and ligaments of knee (S83) & 40 & 87 & 62 to 119 & 43 & 99 & 72 to 134 \\
\hline Acute poisoning (T35-65, T96-T97) & 36 & 130 & 91 to 180 & 49 & 167 & 124 to 221 \\
\hline
\end{tabular}




\begin{tabular}{|c|c|c|c|}
\hline Diagnosis text/area of trade & $\begin{array}{l}\text { Observed } \\
\text { number }\end{array}$ & SHR & $95 \% \mathrm{Cl}$ \\
\hline \multicolumn{4}{|c|}{ Diseases of the circulatory system (100-199) } \\
\hline Seafarers in domestic trade & 113 & 132 & 110 to 159 \\
\hline Seafarers in international trade & 190 & 97 & 84 to 112 \\
\hline \multirow{2}{*}{\multicolumn{4}{|c|}{ > Ischaemic heart disease (120-125) }} \\
\hline Seafarers in domestic trade & & & 67 to 139 \\
\hline Seafarers in international trade & 55 & 83 & 62 to 107 \\
\hline \multicolumn{4}{|l|}{$>>$ Acute myocardial infarction (121) } \\
\hline Seafarers in domestic trade & 11 & 81 & 40 to 144 \\
\hline Seafarers in international trade & 17 & 59 & 34 to 94 \\
\hline
\end{tabular}

classification. The main groups were subdivided for certain diagnostic groups of special interest for seafarers, for example cardiovascular diseases, where the main group was split into acute and primarily non-acute conditions.

\section{RESULTS}

Table 1 shows the standardised hospitalisation ratios for male fishermen and seafarers with at least three months of employment in the business in question. A total of 7401 male seafarers fulfilling the minimum requirement of three months employment in 1995 were included.

Table 2 presents specific data on the hospitalisation of seafarers due to cardiovascular diseases. The seafarers were split into domestic and international trade according to the trade of their first ship in 1995. Seafarers in international trade had lower ratios for hospitalisation in Danish hospitals compared to seafarers in domestic trade with more easy access to a Danish hospital. The standardised hospitalisation ratio for the acute condition acute myocardial infarction was significantly below the average.

In Table 3, the results were classified according to the type of ship the seafarer was employed aboard on the first employment in 1995. A total of 2031 officers belonged to the group "container, dry cargo, tankers", 1258 to the group "coasters and other categories", and 629 to the group "passenger ships". Among the ratings, 1374 belonged to the group "container, dry cargo, tankers", 809 to the group "coasters and other categories", and 1300 to the group "passenger ships". Among the latter, the majority are catering crew, whereas the first two groups are almost all deck and engine room crew.

Officers aboard coasters and "other ships" and ratings aboard passenger ships (mainly catering crew) have high SHRs for gastrointestinal diseases. Both groups have significantly increased levels of hospitalisation due to gastritis: SHR $=286(95 \%$ CI 115 to 588$)$ and SHR $=333(95 \%$ CI 144 to 656), respectively. The ratings aboard passenger ships also had a statistically significant increase of liver disease (K70K77), SHR $=530$ (95\% CI 194 to 1154).

The importance of ship type for the frequency of hospitalisation has been analysed in a Poisson regression analysis and the results are shown in table 4. For all diagnoses included in table 4 , officers had a lower relative risk (RR) in comparison with ratings (reference group). The following diagnostic groups showed a significantly lower relative risk for officers: diseases of the circulatory system $(\mathrm{RR}=0.80,95 \% \mathrm{CI} 0.64$ to 0.99$)$, and injury and poisoning $(\mathrm{RR}=0.69,95 \%$ CI 0.58 to 0.82$)$. Table 5 presents the standardised hospitalisation ratios for female seafarers with at least three months of recorded employment in 1995.

\section{DISCUSSION}

Despite pre-employment selection and bi-annual health examinations, ${ }^{10}$ a large proportion of the seafarers included in this study showed evidence of poor health. Excess risks of hospitalisation were found for several major disease groups. As the study is based on hospitalisations, referral bias may be a potential problem that has to be taken into account when interpreting the results. A large proportion of the seafarers were employed on ships in international trade, and hospitalisations due to acute diseases occurring while abroad will not be included except in cases where the seafarer is repatriated to a Danish hospital. This is clearly shown for acute heart disease, where a remarkable difference was observed between seafarers in domestic trade and seafarers in international trade. This will have a major impact on the true hospitalisation ratio for cardiovascular disease, which will be underestimated in this study. In contrast, the high hospitalisation ratios observed for trauma, intoxication, and other external causes are noteworthy, as the incidents causing hospitalisations abroad are not included. The true risk of hospitalisation due to external causes is thus likely to be even stronger than indicated in the results. In consequence we have not commented on low risks because no interpretation is possible. The underreporting for female seafarers is likely to be less as very few are employed in overseas trade. The classification of the seafarers is based on their first employment in 1995 and is thus a possible bias, as the individuals' status may have changed over time.

The high risk of hospitalisation due to trauma and other external causes corresponds well with a mortality study among Danish seafarers in which high ratios for all causes of violent death are observed..$^{7}$ As in the mortality study, ratings in general have a considerably higher risk in comparison to officers, although officers in small ships also have a high risk compared to males ashore.

The high hospitalisation ratios for cancer also correspond with other observations, ${ }^{8}$ and are likely to be caused by lifestyle related factors. Lung cancer has been shown to be the quantitatively most important contribution to the high mortality due to cancer. ${ }^{7}$ Although the working environment in some cases may contribute, the total impact is likely to be small. ${ }^{11}$

The frequency of diseases of the locomotor system among seafarers clearly differs from the results seen among fishermen. Fishing is known to be a high risk and physically demanding occupation. ${ }^{12}$ The high ratios of disabling conditions such as arthrosis of the hip and knee, or slipped disc of the columna lumbalis seen among fishermen were not found among the seafarers. The strain on the locomotor system is lower on seafarers working on merchant ships compared to the fishermen, where the majority are employed on small 
Table 3 Standardised hospitalisation ratios (SHR) for selected diagnoses among seafarers of different ranks and ship types

\begin{tabular}{|c|c|c|c|c|c|c|}
\hline \multirow[b]{2}{*}{ Diagnosis text/ship type } & \multicolumn{3}{|l|}{ Officers } & \multicolumn{3}{|l|}{ Ratings } \\
\hline & $\begin{array}{l}\text { Observed } \\
\text { number }\end{array}$ & SHR & $95 \% \mathrm{Cl}$ & $\begin{array}{l}\text { Observed } \\
\text { number }\end{array}$ & SHR & $95 \% \mathrm{Cl}$ \\
\hline \multicolumn{7}{|c|}{ Infectious and parasitic diseases (A00-B99) } \\
\hline Container, dry cargo, tankers & 16 & 94 & 54 to 153 & 11 & 91 & 46 to 163 \\
\hline Coasters, other categories & 13 & 125 & 67 to 214 & 7 & 97 & 39 to 200 \\
\hline Passenger ships & 2 & 38 & 5 to 137 & 10 & 90 & 43 to 165 \\
\hline \multicolumn{7}{|l|}{ Neoplasms (COO-C97) } \\
\hline Container, dry cargo, tankers & 43 & 129 & 93 to 174 & 36 & 184 & 129 to 255 \\
\hline Coasters, other categories & 35 & 141 & 98 to 196 & 9 & 93 & 43 to 177 \\
\hline Passenger ships & 13 & 97 & 52 to 166 & 26 & 124 & 81 to 182 \\
\hline \multicolumn{7}{|c|}{ Endocrine and nutritional diseases (EO0-E99) } \\
\hline Container, dry cargo, tankers & 16 & 96 & 55 to 156 & 18 & 175 & 104 to 277 \\
\hline Coasters, other categories & 14 & 121 & 66 to 202 & 10 & 179 & 86 to 329 \\
\hline Passenger ships & 5 & 83 & 27 to 195 & 20 & 192 & 118 to 297 \\
\hline \multicolumn{7}{|c|}{ Diseases of the circulatory system (100-199) } \\
\hline Container, dry cargo, tankers & 68 & 88 & 68 to 111 & 50 & 113 & 84 to 149 \\
\hline Coasters, other categories & 69 & 116 & 91 to 147 & 24 & 111 & 71 to 165 \\
\hline Passenger ships & 31 & 99 & 67 to 141 & 61 & 128 & 98 to 165 \\
\hline \multicolumn{7}{|l|}{$>$ Ischaemic heart disease (I20-125) } \\
\hline Container, dry cargo, tankers & 22 & 82 & 52 to 125 & 12 & 80 & 41 to 140 \\
\hline Coasters, other categories & 23 & 107 & 68 to 161 & 9 & 135 & 62 to 257 \\
\hline Passenger ships & 6 & 51 & 19 to 112 & 14 & 84 & 46 to 141 \\
\hline \multicolumn{7}{|c|}{ Diseases of the respiratory system (J00-J99) } \\
\hline Container, dry cargo, tankers & 34 & 93 & 64 to 130 & 28 & 112 & 74 to 162 \\
\hline Coasters, other categories & 27 & 119 & 78 to 173 & 23 & 158 & 100 to 237 \\
\hline Passenger ships & 13 & 111 & 59 to 189 & 29 & 123 & 82 to 176 \\
\hline \multicolumn{7}{|c|}{ Diseases of the digestive system (KOO-K93) } \\
\hline Container, dry cargo, tankers & 76 & 93 & 74 to 117 & 54 & 105 & 79 to 137 \\
\hline Coasters, other categories & 72 & 133 & 104 to 167 & 31 & 108 & 73 to 153 \\
\hline Passenger ships & 26 & 93 & 61 to 136 & 72 & 143 & 112 to 180 \\
\hline \multicolumn{7}{|c|}{ Diseases of the musculoskeletal system and connective tissue (M00-M99) } \\
\hline Container, dry cargo, tankers & 41 & 65 & 47 to 88 & 35 & 88 & 61 to 122 \\
\hline Coasters, other categories & 36 & 86 & 60 to 119 & 30 & 135 & 91 to 193 \\
\hline Passenger ships & 23 & 108 & 69 to 162 & 41 & 104 & 75 to 141 \\
\hline \multicolumn{7}{|l|}{$>$ Arthrosis of the knee (M17) } \\
\hline Container, dry cargo, tankers & 3 & 80 & 16 to 233 & 3 & 142 & 29 to 416 \\
\hline Coasters, other categories & 3 & 104 & 21 to 304 & 3 & 295 & 61 to 864 \\
\hline Passenger ships & 1 & 65 & 2 to 364 & 3 & 129 & 27 to 378 \\
\hline \multicolumn{7}{|l|}{ > Cervical disc disorders (M50) } \\
\hline Container, dry cargo, tankers & 2 & 129 & 15 to 465 & 2 & 226 & 27 to 815 \\
\hline Coasters, other categories & 4 & 356 & 97 to 912 & 3 & 630 & 130 to 1841 \\
\hline Passenger ships & 0 & 0 & 0 to 542 & 1 & 107 & 3 to 597 \\
\hline \multicolumn{7}{|l|}{ Injury and poisoning (S00-T99) } \\
\hline Container, dry cargo, tankers & 81 & 74 & 58 to 92 & 99 & 125 & 102 to 152 \\
\hline Coasters, other categories & 83 & 131 & 104 to 162 & 91 & 193 & 155 to 237 \\
\hline Passenger ships & 29 & 90 & 60 to 129 & 84 & 117 & 93 to 145 \\
\hline \multicolumn{7}{|c|}{$>$ Fractures ( $\mathrm{S} 02, \mathrm{~S} 12, \mathrm{~S} 22, \mathrm{~S} 32, \mathrm{~S} 42, \mathrm{~S} 52, \mathrm{~S} 62, \mathrm{~S} 72, \mathrm{~S} 82, \mathrm{~S} 92, \mathrm{T02}, \mathrm{T} 08, \mathrm{~T} 10, \mathrm{~T} 12$ ) } \\
\hline Container, dry cargo, tankers & 30 & 88 & 59 to 126 & 33 & 134 & 92 to 188 \\
\hline Coasters, other categories & 34 & 166 & 115 to 232 & 29 & 196 & 131 to 281 \\
\hline Passenger ships & 7 & 68 & 27 to 139 & 35 & 156 & 109 to 217 \\
\hline
\end{tabular}

vessels operating in the rough North Sea. Heavy lifting and other physically demanding tasks are becoming rare aboard merchant ships. This study will, however, not necessarily detect a long term excess risk of diseases of the locomotor system. A healthy worker effect, due to the bi-annual health examinations and self-selection out of the occupation due to symptoms incompatible with working at sea, may possibly have influenced the results. Possible negative health effects may not be visible until late in life and may thus go undetected in the chosen study design with short follow up. ${ }^{13}$

The fishermen also have an excess risk of hospitalisation due to varicose veins of the legs, which may be influenced by long hours standing on a mobile deck cleaning fish. Despite some similar strains on merchant ships, they are in general considerably less, and no excess risk was observed in this study. Prolonged standing at work has been shown to be a risk factor for the occurrence of varicose veins. ${ }^{14}$

It is noteworthy that hospitalisation rates due to lifestyle related diseases such as endocrine and nutritional diseases, including diabetes, are close to normal or even above the mean, despite the fact that the mandatory pre-employment health examinations exclude persons with type 1 diabetes from starting a career at sea. Some exceptions exist, however, for persons who are to work in the galley or catering department. ${ }^{10}$ This may reflect the lifestyle of certain groups of seafarers. Overweight has recently been shown to be considerably more common among Danish seafarers in comparison with the population in general. ${ }^{18}$ Hospitalisation ratios due to gastrointestinal diseases were high among ratings aboard passenger ships. This group is dominated by catering crew and cooks, and may also reflect lifestyle factors including alcohol, active and passive smoking, and nondaytime work. A similar hospitalisation pattern is found among people employed in the Danish hotel and restaurant industry. ${ }^{19}$

The high ratio of hospitalisation due to inguinal hernia is noteworthy as it is likely to be iatrogenic. The seafarers are checked for hernia at bi-annual mandatory health examinations, ${ }^{10}$ which have almost certainly caused many referrals for surgical repair of hernia. Health examinations of fishermen were made compulsory shortly after the end of the study period. 


\begin{tabular}{|c|c|c|}
\hline Diagnosis text/ship type & Relative risk & $95 \% \mathrm{Cl}$ \\
\hline \multicolumn{3}{|c|}{ Infectious and parasitic diseases (A00-B99) } \\
\hline Container, dry cargo, tankers & 1.05 & 0.55 to 2.01 \\
\hline Coasters, other categories & 1.50 & 0.82 to 2.74 \\
\hline Passenger ships & 1.00 & - \\
\hline \multicolumn{3}{|l|}{ Neoplasms (COO-C97) } \\
\hline Container, dry cargo, tankers & 1.59 & 0.97 to 2.62 \\
\hline Coasters, other categories & 1.37 & 0.86 to 2.18 \\
\hline Passenger ships & 1.00 & - \\
\hline \multicolumn{3}{|c|}{ Endocrine and nutritional diseases (EO0-E99) } \\
\hline Container, dry cargo, tankers & 0.95 & 0.53 to 1.73 \\
\hline Coasters, other categories & 1.03 & 0.59 to 1.82 \\
\hline Passenger ships & 1.00 & - \\
\hline \multicolumn{3}{|c|}{ Diseases of the circulatory system (100-199) } \\
\hline Container, dry cargo, tankers & 1.15 & 0.82 to 1.61 \\
\hline Coasters, other categories & 1.25 & 0.92 to 1.69 \\
\hline Passenger ships & 1.00 & - \\
\hline \multicolumn{3}{|l|}{$>$ Ischaemic heart disease (I20-125) } \\
\hline Container, dry cargo, tankers & 1.66 & 0.84 to 3.29 \\
\hline Coasters, other categories & 2.19 & 1.21 to 3.96 \\
\hline Passenger ships & 1.00 & - \\
\hline \multicolumn{3}{|c|}{ Diseases of the respiratory system (J00-J99) } \\
\hline Container, dry cargo, tankers & 1.11 & 0.71 to 1.71 \\
\hline Coasters, other categories & 1.33 & 0.89 to 1.98 \\
\hline Passenger ships & 1.00 & - \\
\hline \multicolumn{3}{|c|}{ Diseases of the digestive system (K00-K93) } \\
\hline Container, dry cargo, tankers & 0.79 & 0.59 to 1.07 \\
\hline Coasters, other categories & 0.98 & 0.74 to 1.30 \\
\hline Passenger ships & 1.00 & - \\
\hline \multicolumn{3}{|c|}{ Diseases of the musculoskeletal system and connective tissue (M00-M99) } \\
\hline Container, dry cargo, tankers & 0.80 & 0.55 to 1.17 \\
\hline Coasters, other categories & 1.09 & 0.77 to 1.53 \\
\hline Passenger ships & 1.00 & - \\
\hline \multicolumn{3}{|l|}{$>$ Arthrosis of the knee (M17) } \\
\hline Container, dry cargo, tankers & 1.33 & 0.29 to 6.23 \\
\hline Coasters, other categories & 1.80 & 0.44 to 7.33 \\
\hline Passenger ships & 1.00 & - \\
\hline \multicolumn{3}{|l|}{ Injury and poisoning (S00-T99) } \\
\hline Container, dry cargo, tankers & 0.99 & 0.78 to 1.27 \\
\hline Coasters, other categories & 1.58 & 1.26 to 1.97 \\
\hline Passenger ships & 1.00 & - \\
\hline \multicolumn{3}{|c|}{$>$ Fractures $(\mathrm{S} 02, \mathrm{~S} 12, \mathrm{~S} 22, \mathrm{~S} 32, \mathrm{~S} 42, \mathrm{~S} 52, \mathrm{~S} 62, \mathrm{~S} 72, \mathrm{~S} 82, \mathrm{~S} 92, \mathrm{~T} 02, \mathrm{~T} 08, \mathrm{~T} 10, \mathrm{~T} 12)$} \\
\hline Container, dry cargo, tankers & 0.92 & 0.61 to 1.39 \\
\hline Coasters, other categories & 1.42 & 0.98 to 2.05 \\
\hline Passenger ships & 1.00 & - \\
\hline
\end{tabular}

In this study, it is shown that seafarers not only have a high burden of hospitalisation due to disease, but also of traumatic incidents causing hospitalisation, despite the underreporting of hospitalisation due to occupational accidents abroad. It is possible that factors causing accidents may go together with factors causing lifestyle related diseases. Similar observations have been made in other settings. ${ }^{16} 17$ Within the group of seafarers, there are considerable differences between different groups of seafarers depending on whether they are officers or ratings. With a few exceptions, ratings had higher hospitalisation ratios compared to officers. This difference is not only seen for hospitalisation due to diseases but also for trauma, intoxication, and other external causes. Ashore, higher social classes in general have a considerably better health in comparison with lower social classes. ${ }^{15}$

Among the officers, remarkable differences in hospitalisation were seen depending on whether they were employed on large or small ships. Officers on large ships, like container vessels, large dry cargo vessels, and tankers did better than officers on the coasters and "other ships" in all main disease categories, but particularly in the category "trauma, intoxication, and other external causes" where the officers serving on large vessels have a statistically lower ratio compared to the male workforce. The officers on small vessels are in general less educated and earn less compared to officers aboard large ships, and thus belong to lower social classes, with the implications this may have on health. Secondly, the results may reflect a selection pattern where officers with poor health, abuse of alcohol, or other problems leave the large ships and seek jobs on small ships, which in general are less regulated. On many large ships, alcohol is totally prohibited.

The results indicate a social gradient among male seafarers and thus also remarkable differences in health within the maritime community itself. Seafarers should be seen as an inhomogeneous group with considerable differences in health, where a well educated group of officers do quite well in comparison with the male workforce in general. Health promotion initiatives targeting seafarers are needed, but should take into account the inhomogeneous composition of the workforce employed aboard merchant ships.

The female seafarers in this study, mainly consisting of women employed in the catering department and the galley, approach the poor profile of the majority of male seafarers, with a high risk of hospitalisation due to diseases related to lifestyle and also external causes. This corresponds well with an earlier study on mortality among female seafarers. ${ }^{20}$ Whether the female seafarers adapt the high risk lifestyle seen among certain groups of male seafarers, or certain 
Table 5 Standardised hospitalisation ratios (SHRs) for selected diagnoses among female seafarers with at least three months employment in 1995

\begin{tabular}{|c|c|c|c|}
\hline Diagnosis text and ICD code & $\begin{array}{l}\text { Observed } \\
\text { number }\end{array}$ & SHR & $95 \% \mathrm{Cl}$ \\
\hline Infectious and parasitic diseases (A00-B99) & 13 & 147 & 78 to 251 \\
\hline Neoplasms (COO-C97) & 39 & 159 & 113 to 217 \\
\hline Diseases of the circulatory system (100-199) & 28 & 181 & 121 to 262 \\
\hline Ischaemic heart disease (120-125) & 2 & 114 & 14 to 413 \\
\hline Myocardial infarction (121) & 0 & 0 & 0 to 536 \\
\hline Varices in the legs & 8 & 206 & 89 to 407 \\
\hline Diseases of the respiratory system (J00-J99) & 16 & 100 & 57 to 163 \\
\hline Diseases of the digestive system (KOO-K93) & 33 & 111 & 77 to 156 \\
\hline Gastric or duodenal ulcer (K25-K27) & 0 & 0 & 0 to 411 \\
\hline Gastritis and duodenitis (K29) & 4 & 369 & 101 to 946 \\
\hline Inguinal hernia (K40) & 0 & 0 & 0 to 645 \\
\hline $\begin{array}{l}\text { Diseases of the musculoskeletal system and connective tissue } \\
\text { (M00-M99) }\end{array}$ & 20 & 91 & 56 to 141 \\
\hline Arthrosis of the hip (M16) & 0 & 0 & 0 to 490 \\
\hline Arthrosis of the knee (M17) & 1 & 131 & 4 to 731 \\
\hline Cervical disc disorders (M50) & 0 & 0 & 0 to 808 \\
\hline Lumbar disc disorders (M51) & 1 & 33 & 1 to 181 \\
\hline Diseases of the genitourinary system (NO0-N99) & 63 & 133 & 102 to 170 \\
\hline Injury and poisoning (S00-T99) & 59 & 181 & 138 to 234 \\
\hline $\begin{array}{l}\text { Fractures (S02, S12, S22, S32, S42, S52, S62, S72, S82, } \\
\text { S92, T02, T08, T10, T12) }\end{array}$ & 21 & 261 & 161 to 399 \\
\hline $\begin{array}{l}\text { Internal iniuries (S15-16, S25-27, S35-37, S45-46, } \\
\text { S55-56, S65-66, S75-76, S85-86, S95-96) }\end{array}$ & 1 & 56 & 2 to 315 \\
\hline $\begin{array}{l}\text { Dislocation, sprain, and strain of joints and ligaments of } \\
\text { knee (S83) }\end{array}$ & 8 & 168 & 73 to 332 \\
\hline Acute poisoning (T35-65, T96-T97) & 12 & 322 & 166 to 563 \\
\hline
\end{tabular}

groups of women with high risk lifestyles are attracted by seafaring, is not known. A combination of both is likely.

In conclusion, we found that despite pre-employment selection, a large proportion of the seafarers constitute a group of workers with evidence of poor health. The subgroups with high risk of hospitalisation due to lifestyle related diseases also had an increased risk of hospitalisation due to injury and poisoning.

\section{Authors' affiliations}

H L Hansen, Medical Office of Health, Vejle County, Denmark F Tüchsen, H Hannerz, National Institute of Occupational Health, Copenhagen, Denmark

\section{REFERENCES}

1 Goethe WHG, Watson EN, Jones DT. Handbook of nautical medicine. Hamburg: Springer Verlag, 1984.

2 Hansen HL, Nielsen D, Frydenberg M. Occupational accidents aboard merchant ships. Occup Environ Med 2002;59:85-91.

3 Moen BE, Nilsson R, Norlinder R, et al. Assessment of exposure to polycyclic aromatic hydrocarbons in engine rooms by measurement of urinary 1 hydroxypyrene. Occup Environ Med 1996;53:692-6.

4 Moen $B E$, Hollund $B E$, Berntsen $M$, et al. Exposure of the deck crew to carcinogenic agents on oil product tankers. Ann Occup Hyg 1995;39:347-61.

5 Hansen HL, Dahl S, Bertelsen B, et al. Lifestyle, nutritional status and working conditions of Danish sailors. Travel Medicine International 1994:12:139-43.

6 Hansen HL, Hansen KG, Andersen PL. Incidence and relative risk for hepatitis $A$, hepatitis $B$ and tuberculosis and occurrence of malaria among merchant seamen. Scand J Infect Dis 1996;28:107-10.
7 Hansen $\mathrm{HL}$, Pedersen G. Influence of occupational accidents and deaths related to lifestyle on mortality among merchant seafarers. Int J Epidemiol 1996;25:1237-43.

8 Andersen A, Barlow L, Engeland A, et al. Work-related cancer in the Nordic countries. Scand J Work Environ Health 1999;25(suppl 2):1-116.

9 Tüchsen $F$, Hannerz $H$, Jensen MV, et al. Socioeconomic status, occupation, and risk of hospitalisation due to coxarthrosis in Denmark 1981-99. Ann Rheum Dis 2003:62:1100-5.

10 Governmental Order No. 903/2000 on Medical Examination of Seafarers and Fishermen. Danish Maritime Authorities, Copenhagen, 2000.

11 Nilsson RI, Nordlinder R, Horte LG, et al. Leukaemia, lymphoma, and multiple myeloma in seamen on tankers. Occup Environ Med 1998;55:517-21.

12 Lawrie T, Matheson C, Murphy E, et al. Medical emergencies at sea and injuries among Scottish fishermen. Occup Med (Lond) 2003;53:159-64.

13 McMichael AJ. Standardized mortality ratios and the "healthy worker effect": scratching beneath the surface. J Occup Med 1976;18:165-8.

14 Tüchsen F, Krause N, Hannerz $\mathrm{H}$, et al. Standing at work and varicose veins. Scand J Work Environ Health 2000;26:414-20.

15 Brønnum-Hansen $\mathbf{H}$, Andersen $\mathrm{O}$, Kjøller M, et al. Social gradient in life expectancy and health expectancy in Denmark. Soz Praventivmed 2004;49:36-41.

16 Rafnsson V, Gunnarsdóttir H. Risk of fatal accidents occurring other than at sea among Icelandic seamen. BMJ 1993;306:1379-81.

17 Juel K. High mortality in the Thule cohort: an unhealthy worker effect. Int J Epidemiol 1996;23:1174-8.

18 Danish Maritime Occupational Health Service. Report from a pilot project. Available from, http://www.seahealth.dk/public/dokumenter temadag2004/mv.pdf (accessed 10 April 2004).

19 Hannerz H, Tüchsen F, Kristensen TS. Hospitalizations among employees in the Danish hotel and restaurant industry. Eur J Public Health 2002; 12:192-7.

20 Hansen HL, Jensen J. Female seafarers adopt the high risk lifestyle of male seafarers. Occup Environ Med 1998;55:49-51. 